\title{
Desain Website Dinas Budaya dan Pariwisata Kota Malang
}

Abstrak-Sebuah kota yang menjadi tujuan wisata Jawa Timur, Ida Ayu Made Wahyuni, menyebutkan budaya Sita Ayu Mayangsari dan Kartika Kusuma Wardani

Departemen Desain Komunikasi Visual, Fakultas

Arsitektur Desain dan Perencanaan,

Institut Teknologi Sepuluh Nopember (ITS)

perlu dikembangkan dengan baik agar dapat menarik wisatawan. Informasi yang diberikan pemerintah dinilai kurang efektif. Pemasaran yang tepat menjadi faktor penting dalam meningkatkan visibilitas pariwisata kota. Pentingnya pemasaran yang baik menimbulkan urgensi untuk membuat suatu media yang informatif dan persuasif salah satunya melalui media website. Metode yang digunakan untuk menyelesaikan permasalahan tersebut adalah metode observasi mengenai kelebihan dan kekurangan objek wisata, dept interview mengenai penelusuran masalah dengan stakeholder, wisatawan dan pengelola objek wisata, kuesioner tentang desain, fitur, konten pada website. Studi literatur pada buku, jurnal terkait, serta metode studi eksisting untuk menambah referensi dalam perancangan. Hasil dari perancangan ini adalah media promosi berupa website pariwisata kota Malang yang mengusung konsep Fun, Friendly, dan Responsive didukung oleh fitur tour itinerary dan gaya desain custom illustration. Perancangan website Dinas Budaya dan Pariwisata ini diharapkan mampu menjadi media yang informatif dan persuasif bagi masyarakat.

Kata Kunci-Website, Budaya, Pariwisata, Promosi, Malang.

\section{PENDAHULUAN}

AWA timur memiliki berbagai macam tempat pariwisata yang tersebar di 38 kabupaten kota.

Dengan beragam wisata yang khas mulai dari pegunungan, pantai, air terjun, hingga budaya. Gubernur Jawa timur, Soekarwo mengatakan bahwa provinsi Jawa Timur ini bisa menjadi destinasi wisata terkemuka di dunia. Salah satu tempat wisata dan budaya tersebut adalah kota Malang. Kota Malang saat ini telah menjadi salah satu primadona pariwisata nasional seperti Bali, dan Jogjakarta karena berbagai keunikan, keindahan alam, dan kreativitas industrinya.

Malang memiliki berbagai macam wisata yang ditawarkan seperti wisata kuliner, wisata event, wisata heritage, wisata budaya, wisata religi, wisata alam, dan yang baru adalah wisata tematik. Kepala Dinas Budaya dan Pariwisata Malang, memberikan sumbangan terbesar pada sektor pariwisata. Menurut data yang dikutip dari Kepala Dinas Budaya dan Pariwisata Malang, sebanyak $60 \%$ kecenderungan wisatawan mancanegara untuk hadir ke suatu daerah karena adanya faktor budayanya kemudian 30\% karena faktor alam, dan $10 \%$ pada faktor buatan.

Untuk menunjang pengembangan pariwisata Malang seperti wisata-wisata heritage, kampung tematik, dan event tersebut, pemerintah terus melakukan sejumlah upaya termasuk dalam hal penyampaian informasi dan promosi kegiatankegiatan yang dapat diakses oleh semua lapisan masyarakat yang ingin mengetahui apa saja yang ada di pariwisata Kota Malang. Seiring dengan berkembangnya teknologi, berkembang pula perilaku konsumen yang memanfaatkan akan keberadaan teknologi. Salah satu yang paling diminati oleh masyarakat saat ini adalah media online atau internet. Banyak sekali berita, informasi umum, periklanan yang menggunakan media internet sebagai promosi yang berupa website.

Sebuah kota yang menjadi tujuan wisata perlu dikembangkan dengan baik agar dapat menarik wisatawan. Informasi yang diberikan selama ini dinilai kurang informatif. Pemasaran yang tepat menjadi faktor penting dalam meningkatakn visibilitas suatu daerah tersebut. Pentingnya pemsaran yang baik menimbulkan urgensi untuk membuat suatu media pemasaran dengan konten yang informatif dan persuasif, salah satunya melalui media website. Untuk itulah perlu diadakan riset mengenai website untuk wisatawan. Rumusan masalah dalam penelitian ini adalah: Bagaimana cara merancang website Dinas Budaya dan Pariwisata Kota Malang yang informatif sesuai kebutuhan dan menarik bagi wisatawan baik lokal maupun mancanegara?

Dengan Batasan masalah diantaranya adalah pembahasan hanya meliputi perancangan dengan output berupa interface dan experience website dengan tujuan salah satunya untuk memberikan kemudahakan akses dalam mendapatkan informasi mengenai segala hal 
yang berkaitan dengan konten pariwisata dart budaya di Kota Malang serta mengangkat potensi pariwisata di kota Malang agar lebih dikenal oleh kalangan masyarakat luas baik lokal maupun internasional sekaligus menaikkan tingkat perekonomian daerah.

\section{STUDI PUSTAKA}

\section{A. Pariwisata}

Menurut Macintosh dan Goeldner, Pariwisata adalah suatu kumpulan kegiatan, layanan dan industri yang diberikan melalui pengalaman perjalanan yang mencangkup transportasi, akomodasi, tempat makan dan minum, toko retail, tempat hiburan dan layanan tempat menginap yang disediakan baik untuk individu atau kelompok yang sedang berpergian jauh dari rumah. Kota Malang terkenal sebagai kota pariwiata dengan berbagai macam fasilitas dan pendukung lainnya, diantaranya:

1. Keindahan alam dan panorama yang indah dan hawa yang sejuk

2. Banyaknya peninggalan bangunan atau gedung masa colonial Belanda

3. Kampung-kampung tematik

\section{B. Motivasi Wisata}

Motivasi yang mendorong seseorang untuk 1. melakukan perjalanan adalah sebagai berikut: To escape (kabur)

2. Social needs (kebutuhan social)

3. Self esteem (harga diri)

4. Relax (bersantai menghilangkan stress)

\section{Desain Website}

1. Layout

Untuk grid layout terdiri dari tiga elemen: coloumn, gutters, dan margin. Lebar kolom ditentukan breakpoint dimana layar dilihat apakah itu breakpoint ponsel, tablet atau ukuran lainnya.

2. Color

Warna sangat berpengaruh dalam sebuah desain. Warna memiliki karakter tersendiri dan mencerminkan suasana tertentu. Skema warna dalam desain harus bisa mewakili karakter yang diinginkan, tetapi penggunaan warna yang berlebihan juga akan mengalihkan pengunjung dari konten website yang disajikan.

3. Ikon

Ikon merupakan sebuah elemen dalam UI graphic design yang berguna untuk menyampaikan informasi dalam bentuk ikon. Ikon lebih dari sekedar gambar dimana fungsionalitasnya tersirat oleh representasi visual. Pada website terdapat guideline dalam pembentukan besaran sebuah ikon.

\section{Tipografi}

Tipografi merupakan penataan visual dari sekumpulan kata. Teks harus mudah dibaca, hal ini bisa dicapai dengan mengatur kontras warna teks dengan background. Selain itu penggunaan font yang tepat juga perlu diperhatikan, jenis font, ukuran font, style dan konsistensinya dalam desain. Menurut tipe desain material ada 13 jenis gaya yang didukung oleh sistem terhadap kategori teks.

5. Graphic User Interface

User interface atau antar muka merupakan mekanisme komunikasi antara pengguna (user) dengan sistem. User interface dapat menerima informasi dari pengguna dan memberikan informasi kepada user untuk membantu mengarahkan alur penelusuran masalah sampai ditemukan suatu solusi.

\section{Tren Website Tahun 2017-2018}

Tren yang terjadi pada website tentunya terus mengalami perkembangan setiap tahunnya. Berikut adalah kumpulan beberapa tren website pada tahun 2017-2018.

1. Colorful Pages \& Gradient

2. Drop shadow and drop

3. Particle background

4. Custom Illustration

\section{E. Studi Eksisting}

Studi eksisting dilakukan untuk menilai performa dan mengetahui kelebihan dan kekurangan dari studi eksisting yang ada. Berikut beberapa website yang dijadikan sebagai studi eksisting:

1. Beautiful Malang

2. Banyuwangi Tourism

\section{F. Studi Komparator}

Studi komparator dilakukan untuk mengetahui kelebihan dan kekurangan dari studi eksisting yang ada. Berikut beberapa website yang dijadikan sebagai studi komparator: 1. Visit Singapore

2. Sparkling Surabaya 


\section{METODOLOGI PERANCANGAN}

\section{A. Alur Perancangan}

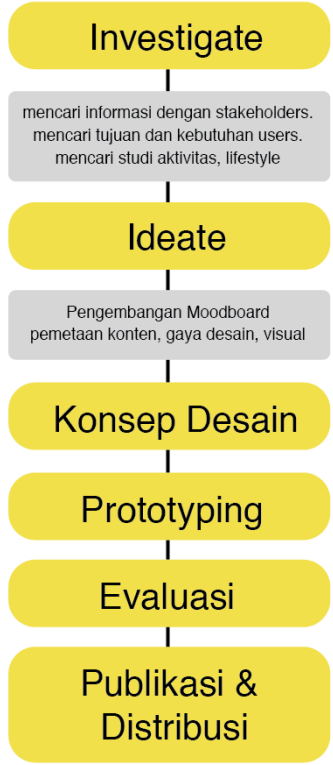

Gambar 2. Bagan alur perancangan.

\section{B. Pengumpulan Data}

Dalam proses penelitian ini terdapat data primer dan sekunder yang digunakan. Berikut ialah penjabaran metode pengambilan data yang digunakan:

1. Data Primer

Hasil dari data primer kemudian dianalisis kembali untuk menemukan rumusan kebutuhan user, motivasi yang mendorong ketertarikan berwisata, serta solusinya dalam desain.

a. Kuesioner tentang desain, fitur, konten yang akan disajikan pada website.

b. Observasi mengenai kelebihan dan kekurangan objek wisata

c. Dept interview mengenai penelusuran masalah dengan Kabid pariwisata kota Malang, Bapak Agung, wisatawan dan pengelola objek wisata

2. Data Sekunder

a. Studi literature pada buku dan jurnal terkait

b. Studi eksisting pada website visit Singapore, banyuwangi tourism untuk menambah referensi perancangan.

\section{KONSEP DESAIN}

\section{A. Deskripsi Perancangan}

Produk yang dihasilkan adalah berupa media website dengan format html yang mengangkat konten pariwisata budaya kota Malang. Konsep yang digunakan pada website ini adalah Fun, Friendly dan Responsive dengan didukung fitur tour dan itinerary juga gaya desain custom illustration.
B. Keywod

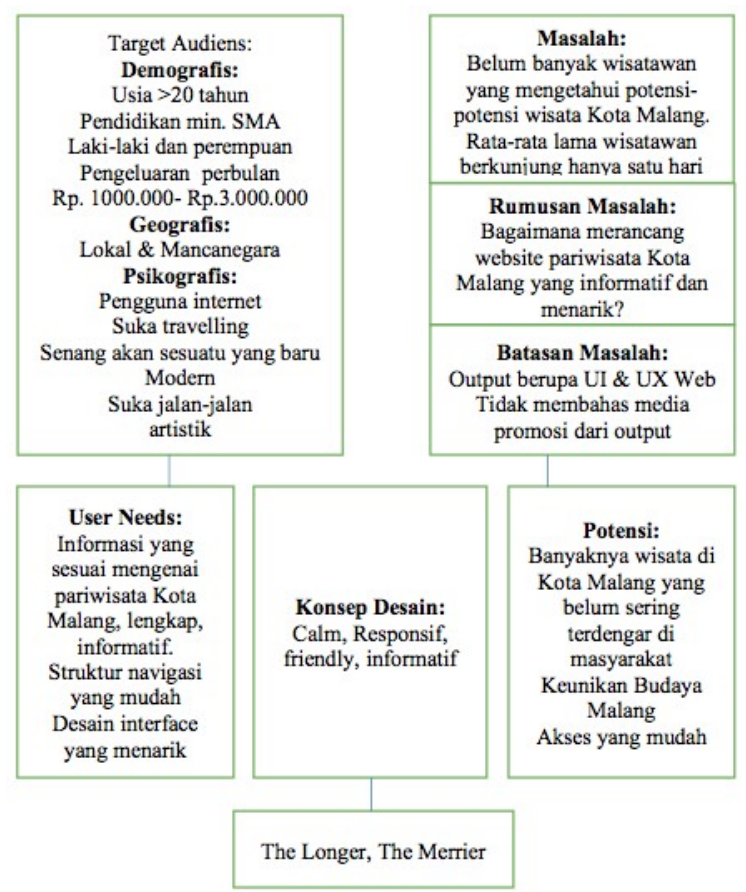

Gambar 3. Tabel Penentuan Keyword.

Makna dari konsep "The Longer, The Merrier" adalah semakin lama wisatawan menjelajah Kota Malang semakin menyenangkan pengalaman yang akan didapat. Kalimat the longer, the merrier yang berarti "semakin" dipakai untuk menunjukkan bahwa ada sesuatu dalam hal pengalaman yang bisa didapatkan dan dirasakan oleh wisatawan. "The Longer, The Merrier" yang berarti semakin lama wisatawan tinggal semakin menyenangkan pengalaman yang akan didapat.

\section{Kriteria Desain}

Untuk membuat desain website yang menarik dan memenuhi kebutuhan user website harus menunjukkan tawaran sesuai dengan motivasi user dalam berwisata. Untuk itu website harus memiliki kriteria sebagai berikut:

Arsitektur Informasi

Website harus memuat informasi tentang kota malang, destinasi wisata, traveler info, events, paket wisata dan workshop. Menunjukkan kualitas pariwisata yang baik dan dengan membuat fitur tour beserta itinerary dan juga membuat segmentasi khusus yaitu kelas workshop untuk bidang seni dna budaya di kota Malang.

Konten

Konten yang menarik bagi user calon wisatawan adalah konten yang sesuai dengan motivasi user untuk berwisata. Untuk itu konten harus bersifat persuasive dengan menggunakan Bahasa sehari-hari. Informasi yang dibutuhkan adalah informasi mengenai obyek wisata, transportasi, penginapan, dan kuliner serta 
kegiatan-kegiatan yang dapat dilakukan di kota malang.

3. User Interface

Website menggunakan elemen visual berupa ilustrasi, dan gambar untuk mengurangi informasi dengan teks secara berlebihan. Website dirancang juga dengan fitur online chat untuk meningkatkan interaktifitas antara user dan website.

4. User Experience

Website bersifat responsive dan bisa digunakan dengan nyaman baik di desktop maupun melalui smarphone. Website menyediakan fitur-fitur seperti fitur favorit untuk mengumpulkan atau melakukan filter informasi kemudian fitur chat online sehingga memudahkan user untuk, berkomunikasi secara cepat dengan admin.

\section{Penerapan Desain}

Berikut ini merupakan penerapan desain pada pembuatan website pariwisata kota malang berdasarkan kriteria desain di atas:

1. Layout

Jenis layout yang sesuai dengan format tersebut adalah layout dengan grid bootstrap yaitu memiliki baris maksimal 12 kolomb. sehingga memudahkan sistem navigasi bagi user.

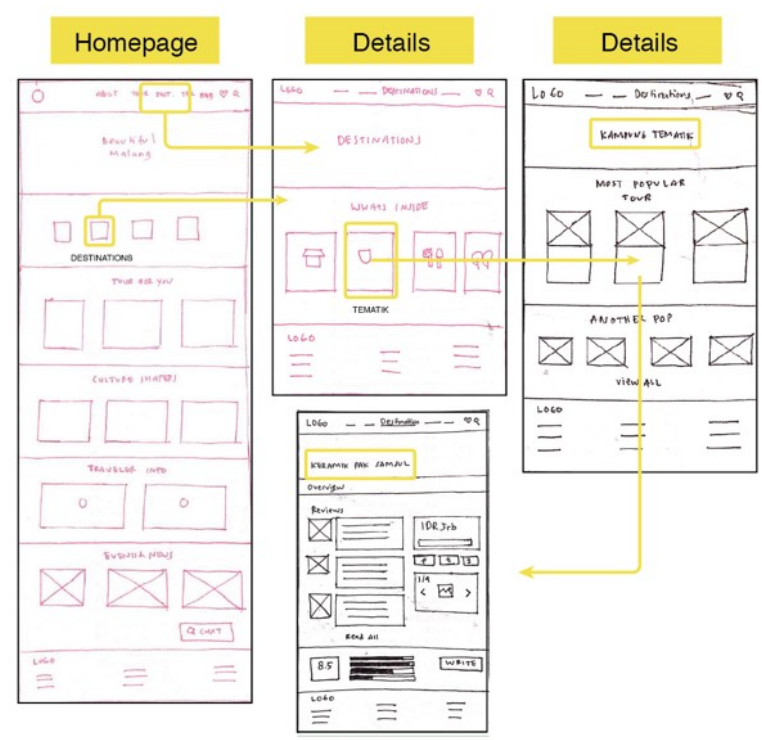

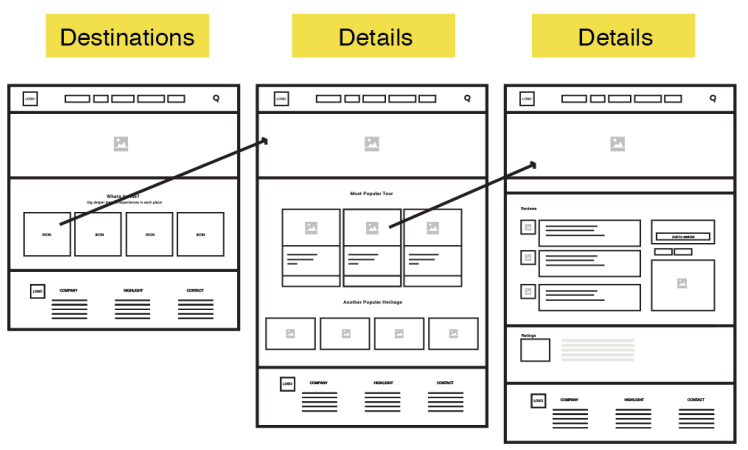

Gambar 4. Sketsa Wireframe layout website.

Ilustrasi
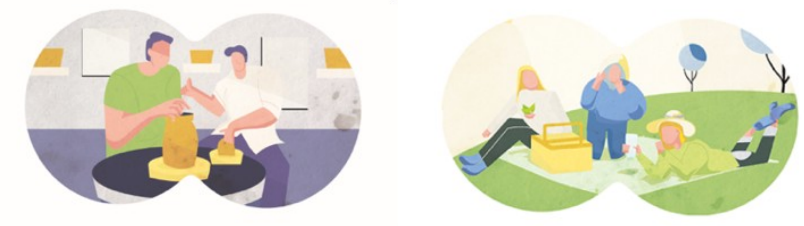

Gambar 5. Ilustrasi website.

Ikon

Jenis ikon yang digunakan adalah stroke ikon dimana bentukan dibuat sederhana dan umum sesuai dengan kebutuhan konten.

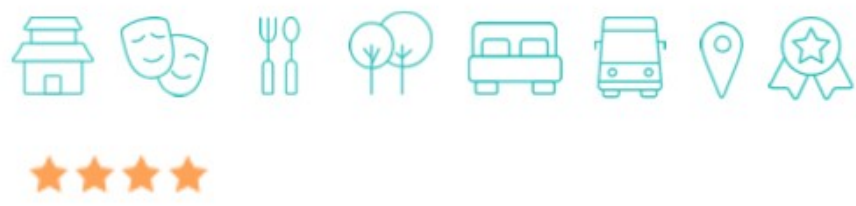

Gambar 6. Ikon website.

4. Elemen User Experience

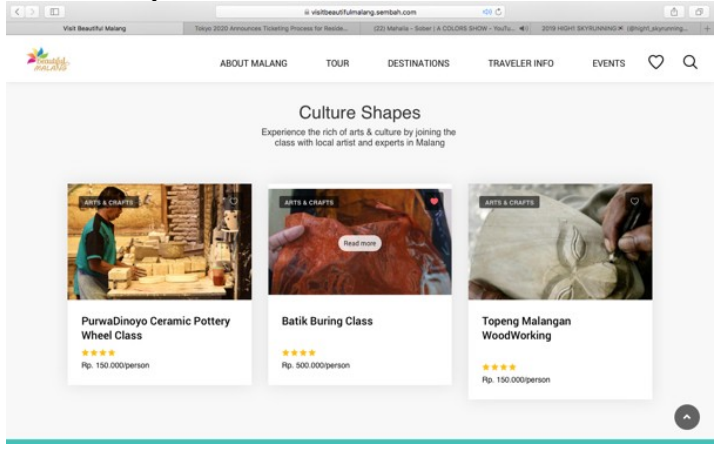

Gambar 7. Desain Navigasi dan Desain Fitur Favorit. 


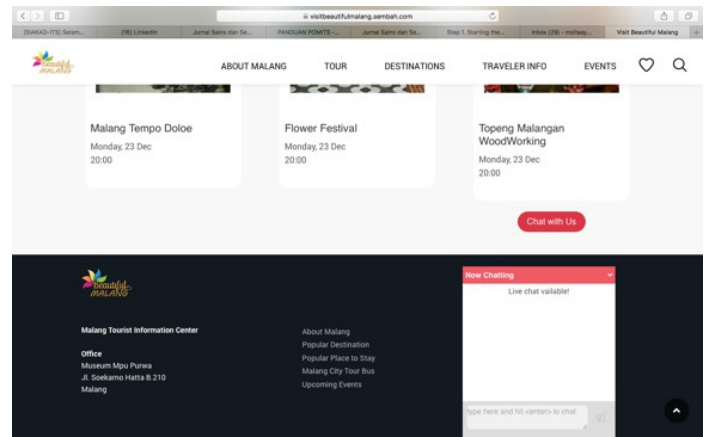

Gambar 8. Desain Navigasi dan Desain Fitur Live Chat

\section{DESAIN AKHIR}

\section{A. Homepage}

Homepage adalah halaman pertama pada website yang berisi informasi umum mengenai keseluruhan konten yang diberikan. (Gambar 9)

Culture shapers merupakan halaman khusus untuk penawaran kegiatan workshop yang berkaitan dengan bidang seni dan budaya. Hasil akhir website terdiri dari 5 menu utama yaitu: about malang, tour, destinations, traveler info, dan events.

\section{B. Destinations}

Halaman destinations adalah halaman yang memuat informasi berupa tujuan wisata yang terbagi menjadi 4 kategori yaitu heritage, kampung tematik, kuliner, dan taman.
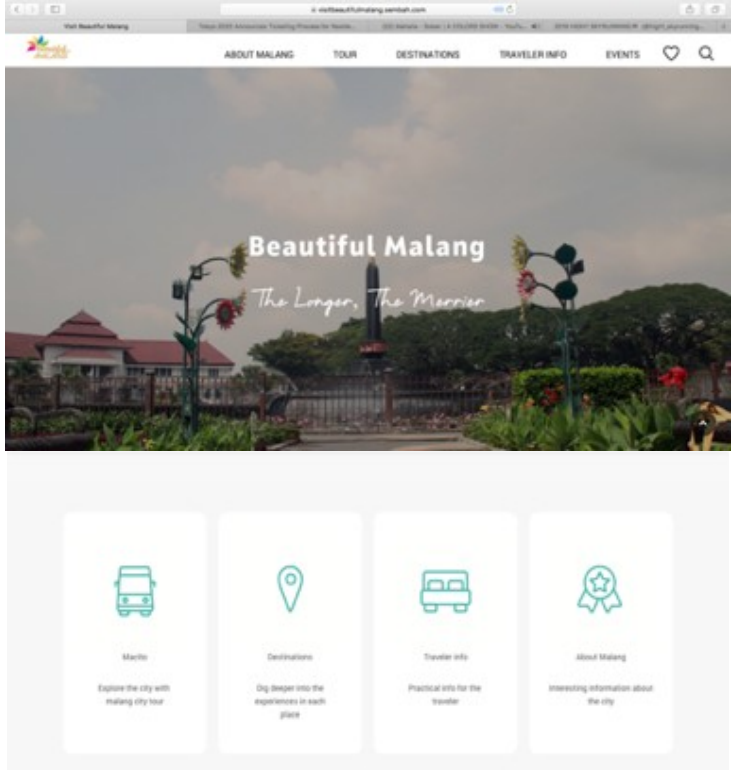

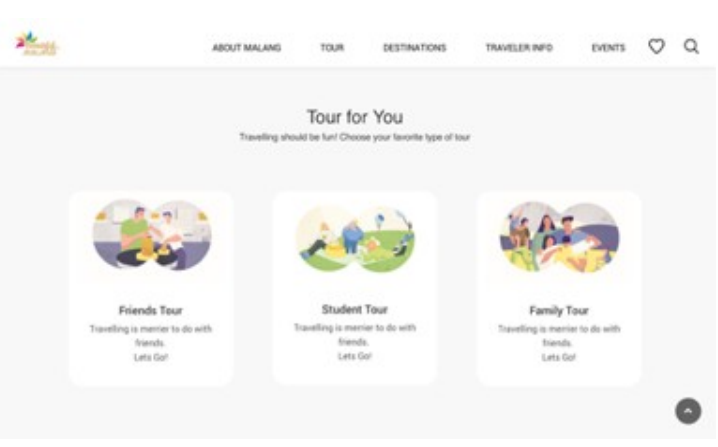

Gambar 9. Desain homepage website malang tourism.
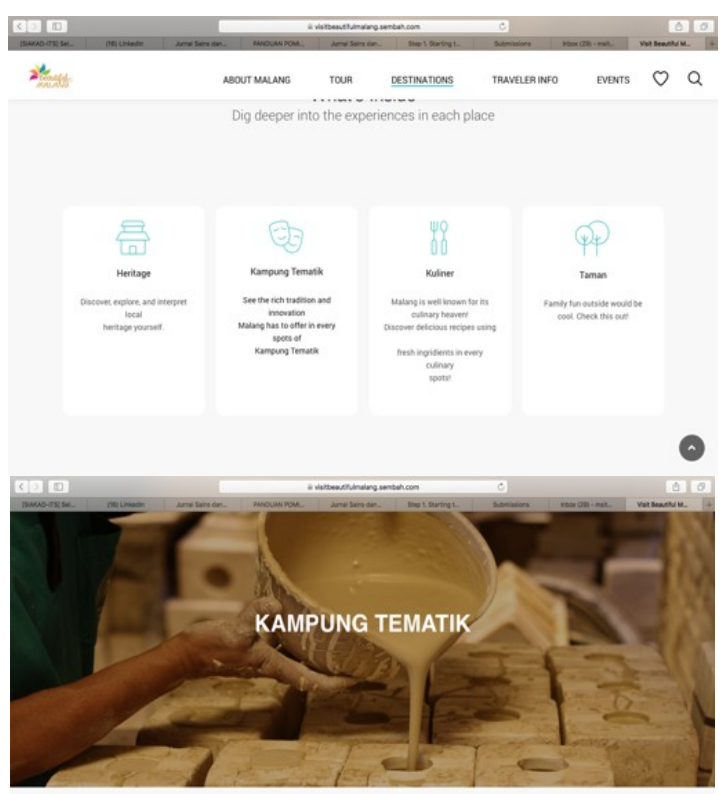

Most Popular Tour

We present our most popular tourism object

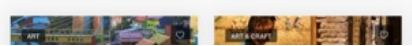

Gambar 10. Desain halaman destination website malang tourism

\section{Media Promosi}

Media promosi yang digunakan untuk menyebarkan informasi lainnya berupa promosi dalam bentuk cetak yaitu iklan pada majalah, postcard dan perangko.

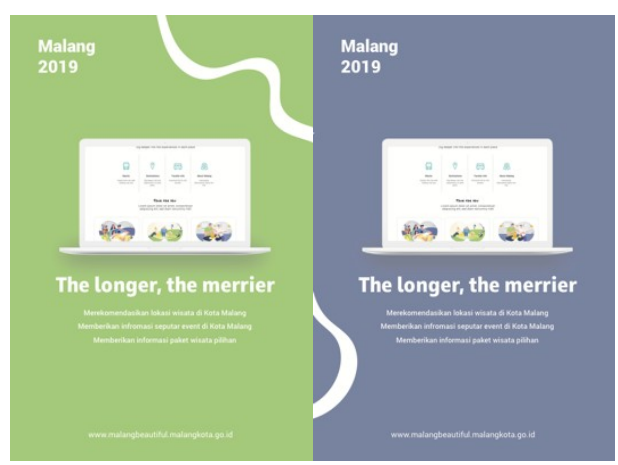

Gambar 11. Media promosi website malang tourism. 
D. Mockup

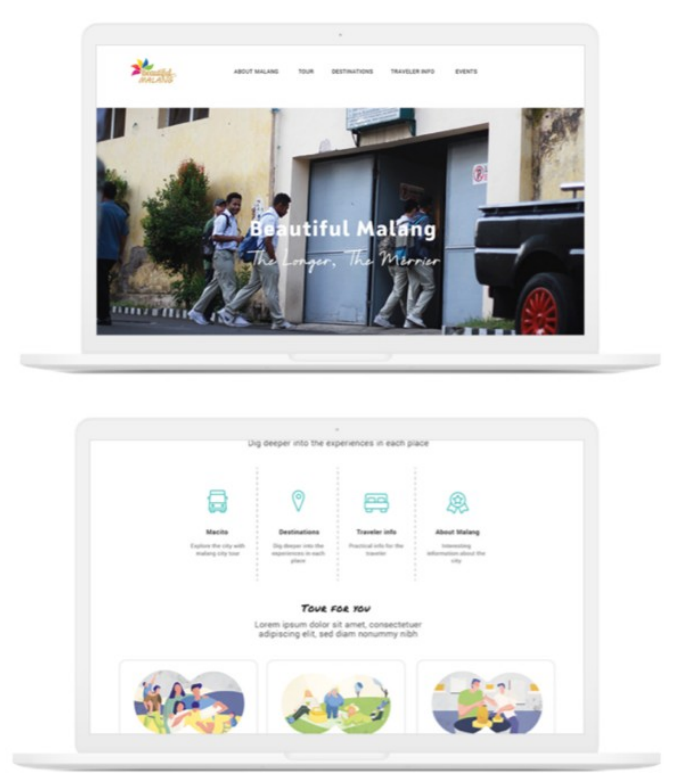

Gambar 12. Mockup website final.

Gambar di atas adalah tampilan awal pada homepage website Dinas budaya dan pariwisata kota malang.

\section{KESIMPULAN}

Setelah melalui seluruh rangkaian penelitian dapat disimpulkan beberapa hal sebagai berikut:

1. Pada keseluruhan proses perancangan dilakukan dua kali User Test, yaitu pada saat perancangan sampai pada tahap prototyping
User Interface dan pengujian akhir pada saat sudah berbentuk prototype website yang dapat berfungsi.

2. Dari hasil pengujian pertama user interface, masukan dan saran yang diberikan oleh user menjadi pertimbangan untuk merancang desain akhir website

3. Dari hasil pengujian akhir, desain website sudah memiliki perbedaan gaya ikon dan warna sebagai ciri khas untuk dibandingkan dengan website eksisting

4. Kedepan user ingin menggunakan website ini sebagai media untuk mencari informasi dan akan menyarankan ke orang lain untuk mengunjungi website baru pariwisata kota malang.

\section{DAFTAR PUSTAKA}

[1] Dartika. 2010. Peran dan fungsi website dalam pemerintahan sebagai sarana komunikasi yang efektif

[2] Destiana, Winda. 2017. Malang pahami cara hadapi wisatawan

[3] Condratov, I. 2013. Tourism- Concept and Evolution

[4] Hartik, Andi. 2017. Wisatawan Mancanegara menyukai wisata heritage Oates, Greg. 2015. Tourism Australia uses food to drive luxury travel spending.

[5] Peltier, Dan. 2017. 25 Best tourism board websites in the world in 2017

[6] Raposo, Rui, and Pedro, Beca. 2013 A Concept where Mobile Tourism Meets Participatory Culture

[7] Ridder, D. Lennard. 2018. 9 Cutting Web Design Trends for 2018.

[8] RP, Creatim. 2018. Tourism website design in 7 steps.

[9] Statista. 2018. Percentage of all global web pages served to mobile phones from 2009 to 2018

[10] Werthner, H. 2004. E-Commerce and Tourism. Communication of the ACM (47), 101-105

[11] Yoeti, O.A. 1997. Perencanaan dan Pengembangan Pariwisata, PN PT. Pradaya Paramita Jakarta.

[12] Zheng, David. 2013. Travel website that will get you moving. 